\title{
Institutional Distance, Bilateral Political Relations and the Success or Failure of Chinese Enterprises' Foreign Direct Investment
}

\author{
Wei Qian \\ Business School, Nanjing Normal University, Nanjing, China \\ Email: wicher2369@163.com
}

How to cite this paper: Qian, W. (2019) Institutional Distance, Bilateral Political Relations and the Success or Failure of Chinese Enterprises' Foreign Direct Investment. Open Journal of Social Sciences, 7, 198-214.

https://doi.org/10.4236/jss.2019.711014

Received: October 22, 2019

Accepted: November 17, 2019

Published: November 20, 2019

Copyright () 2019 by author(s) and Scientific Research Publishing Inc. This work is licensed under the Creative Commons Attribution International License (CC BY 4.0). http://creativecommons.org/licenses/by/4.0/

\begin{abstract}
However, among global foreign investment, the failure rate of Chinese enterprises' foreign direct investment has remained high. By analyzing the tracking data of China's large-scale foreign investment in 2005-2016, this paper studies the relationship between institutional distance, bilateral political relations and the success or failure of Chinese enterprises' foreign direct investment. The results show that institutional distance and bilateral political relations have a significant impact on the success or failure of foreign direct investment, and bilateral political relations have a negative regulatory effect on the relationship between institutional distance and the success or failure of foreign investment. The nature of corporate property rights will also play an important role in the regulation of bilateral political relations.
\end{abstract}

\section{Keywords}

Institutional Distance, Bilateral Political Relations, The Nature of Corporate Property Right

\section{Introduction}

After the outbreak of the financial crisis in 2008, the global economy has been greatly affected, and overseas investment by Chinese companies has been in full swing. According to the statistics of the Ministry of Commerce, the amount of foreign direct investment of Chinese enterprises in 2018 has reached US \$129.83 billion, which has become one of the world's largest foreign investment countries. However, the reality is that the failure rate of Chinese companies' foreign investment remains high. According to the Financial Times, in 2016 the total amount of overseas transactions cancelled in China exceeded US $\$ 75$ billion. 
More than 30 acquisitions of European and American companies were forced to "abort" due to regulatory and foreign exchange restrictions. In 2015, the amount of cancelled transactions was approximately $\$ 10$ billion. Throughout the case of overseas investment failure of Chinese enterprises, the causes of transaction failure are complex and diverse, not only affected by economic factors such as market and resources, but also by non-economic factors such as the political risk and institutional environment of the host country. For example, in 2008, the acquisition of the Dresdner Bank by the National Development Bank was terminated by Germany on the grounds of "endangering national security". With the difficulties of various countries, it is hard for Chinese companies to invest overseas.

Chiese government has been actively promoting the building of the Belt and Road, which has brought huge opportunities to enterprises, but also brought corresponding competition and challenges. Therefore, Chinese enterprises face more risks and uncertainties in the process of international investment. This shows that political and institutional risks have become an important factor in restricting Chinese companies' foreign investment. About institutional risk in foreign investment, the existing literature discusses the relationship between institutions and corporate foreign investment in terms of acquisition experience, holding ratio, institutional quality and distance, and a large number of scholars have studied the relationship between institutional risks and foreign investment. Yang Lianxing and others studied the impact of bilateral political relations and foreign investment and the success or failure of investment. They believed that friendly city communication can significantly increase the success rate of foreign investment [1].

This paper specifically analyzes the direct and indirect effects of bilateral political relations on the success or failure of Chinese enterprises' foreign direct investment. On the one hand, it is conducive to the foreign investment of enterprises with Chinese characteristics, making full use of bilateral political relations with host countries, breaking trade barriers with good political relations, participating in international cooperation, and helping achieve trade and economic prosperity between China and the world. On the other hand, it enables Chinese companies to identify problems in the process of foreign investment, including factors such as industry, resources and market. By maintaining political relations with the host country, the Chinese government can improve the efficiency of investment, which is of great significance to promote the development of international trade of Chinese enterprises.

\section{Literature Review}

\subsection{The Eclectic Theory of International Production}

The Eclectic Theory of International Production believes that enterprises must have the advantages of ownership, location and market internalization for international direct investment. Dunning refers to the three basic elements of international direct investment as the OLI model [2]. At the same time, he also 
proposes that the advantages of ownership and internalization are only necessary for foreign direct investment. Only by satisfying these two necessary conditions, foreign direct investment will be the best choice for enterprises.

Focusing on overseas investment by Chinese companies, Buckley et al. studied the factors that influence Chinese companies' foreign direct investment [3]. They believe that the political risks of host countries have a negative impact on Chinese companies' foreign direct investment.

\subsection{Institutions and Related Theories}

In North, institution is a kind of social game rule [4]. This kind of rule is designed by the society to regulate and shape the behavior of members of society, both formal and informal. Rui and other researchers believe that Chinese companies' foreign investment is subject to the background of the host country [5]. Kolstad and Wiig studied the relationship between the host country system and Chinese companies' overseas investment, and found that Chinese companies' overseas investment may take advantage of the defects of the host country system to seek benefits, so the institutional risk of the host country will not hinder China's capital inflow [6]. Habib and Zurawicki studied foreign investment in developed countries and found that institutional differences were negatively correlated with foreign investment [7]. Due to the diversity of politics, history and culture, there are huge differences between different countries' systems, and institutional differences between countries will have different effects on the internationalization behavior of enterprises [8].

The institutional environment difference between the home country and the host country is defined by Kostova as institutional distance [9]. Zhang Jianhong and Zhou Chaohong studied the impact of institutional quality on the success or failure of overseas mergers and acquisitions from an institutional perspective, and found that the quality of host country systems has a negative regulatory effect on the relationship between industrial protection and acquisition experience and the success or failure of overseas acquisitions [10]. When Morosini studied the relationship between cultural distances between countries and the performance of overseas M\&A, it was found that the greater the cultural differences between the two countries, the more unfavorable the companies engaged in overseas mergers and acquisitions [11]. Jing Li found that bilateral political relations are significantly positively related to foreign investment [12]. Gupta also pointed out that foreign investors will consider the impact of bilateral relations when making cross-border investments [13]. The deterioration of bilateral relations between the two countries will seriously reduce the foreign investment in domestic enterprises.

\subsection{Current Research Situation at Home and Abroad}

Zhang Jianhong discusses the factors that determine the success or failure of Chinese companies' overseas mergers and acquisitions from all angles. They be- 
lieve that the main reasons for the failure of overseas acquisitions are politics and economy [14]. Jiang Guanhong analyzes the influence of institutional differences and cultural distances on China's foreign investment risk. It is found that the more stable the host country's politics, the higher the legal system quality, the better the corruption control and the higher the government efficiency, the lower the risk of foreign investment [15]. Pan Zhen and Jin Zhongkun examined the mechanisms and effects of bilateral political relations and host country system risks affecting foreign investment. They found that in a host country with high institutional risk, good bilateral diplomatic relations can promote foreign investment [16]. Yang Lianxing et al. found that friendly bilateral diplomatic relations can promote the development of foreign investment [17]. Zhang Jianhong and Jiang Jiangang found that diplomatic relations can effectively promote the development of foreign investment, and bilateral diplomatic activities can also protect sensitive industries while overcoming the adverse effects of imperfect host country systems [18].

In recent years, the analysis of the reasons for the failure of Chinese enterprises' foreign direct investment has become a hot topic for domestic scholars. Yan Daying believes that the formal and informal institutional distance has a significant negative impact on the success of Chinese companies' overseas mergers and acquisitions, and the accumulation of international experience can significantly weaken the adverse impact of institutional distance on the success rate of overseas mergers and acquisitions [19]. Jia Jingyu and Li Wen studied the impact of distance, strategic motivation and the success or failure of foreign investment [20]. It was found that the formal institutional distance significantly reduced the success rate of M\&A and was positively regulated by the natural resource seeking motivation. Li Shi and Wu Chaopeng analyzed the influencing factors of the success of Chinese companies' cross-border mergers and acquisitions based on political and cultural perspectives. They found that the success rate of mergers and acquisitions involving politically sensitive industries is low, and the diplomatic relations between China and the host countries [21]. The more intimate and the higher the level of mutual trust, the more likely it is to complete the completion of the M\&A transaction. Chen Yan and Guo Wenbo found that the relationship between institutional risk and cross-border M\&A success rate has a significant negative correlation between institutional risk and transnational succession [22]. Good bilateral diplomacy can weaken the negative impact of institutional risk. Compared with non-state-owned enterprises, state-owned enterprises have more political influence from their home countries. Yang Lianxing et al. believe that good bilateral relations have complementary effects on the institutional environment of the host country, both formal and informal, which can promote foreign investment and significantly increase the success rate of foreign direct investment [17].

The existing literature has studied the relationship between institutional distance and foreign investment. It is found that the larger the institutional distance, the more difficult it is for enterprises to adapt to the investment environ- 
ment of the host country, resulting in the decrease in foreign investment [23]. Based on current research, scholars also analyze the impact of different bilateral relations on corporate foreign investment from the perspective of bilateral political relations. Good bilateral political relations can promote foreign investment, while deteriorating bilateral relations will reduce foreign investment. At present, Chinese companies' overseas investment has been frustrated repeatedly, and a large amount of research has focused on analyzing the failure of enterprises' foreign investment [24]. From the perspective of the existing investment success and failure literature, most scholars analyze the impact of different dimensions on the success or failure of the company's foreign investment from the perspective of transaction costs and "outsider disadvantages", pointing out that both formal institutional distance and cultural distance will reduce the enterprise and the success rate of foreign investment [10]. At the same time, scholars study the reasons for the failure of Chinese enterprises' foreign investment from political relations, institutional risks, international experience and other factors, and also specifically study the relationship between institutional distance and the success or failure of foreign investment, that is, the institutional distance will reduce the success rate of corporate investment. However, there are few documents that combine bilateral relations with institutional distances, and analyze the reasons for the failure of foreign investment from the two main perspectives of politics and institutions.

\section{Research Hypothesis}

\subsection{Institutional Distance and the Success or Failure of Chinese Enterprises' Foreign Investment}

North believes that the way and results of transactions are closely related to the institutional environment [4], so institutional differences in different countries will affect the outcome of foreign investment. This paper chooses the definition of Kostova and believes that the bilateral institutional distance is the environmental difference between the home country and the host country [9]. Yan Daying pointed out the relationship between institutional distance and overseas mergers and acquisitions: the larger the distance between bilateral institutions, the more difficult it is for foreign investors to adapt to and comply with local laws and regulations, which will reduce the unpredictability of transactions and greatly increase mergers and acquisitions. It will have a significant negative impact on the success of overseas mergers and acquisitions [19]. Jia Jingyu and $\mathrm{Li}$ Wen studied the distance and the success of Chinese enterprises' cross-border mergers and acquisitions. It was found that the large bilateral system distance makes it difficult for M\&A companies to correctly interpret the political environment, M\&A procedures and economic rules of the host country [20]. The difficulty for the host country to obtain "legality" is more likely for home country investors to be resisted by host country stakeholders, so as to reduce the likelihood of successful M\&A. Therefore, in cross-border investment, if there are big 
differences in the political system, legal norms and economic policies between the host country and the home country, it is difficult for investors to adapt to the local institutional environment in the short term, which will lead to greater uncertainty in the transaction, and increase in transaction costs. At the same time, the huge institutional distance makes transnational transactions highly complex and unpredictable, resulting in information asymmetry between the two sides, which increases the difficulty of foreign investment [25]. Based on the above analysis, we propose the following assumptions:

Hypothesis 1: Bilateral institutional distance has a negative impact on the success rate of foreign investment, that is, the larger the distance between bilateral systems, the lower the success rate of foreign investment.

\subsection{Bilateral Political Relations and the Success or Failure of Chinese Enterprises' Foreign Investment}

In essence, political relations are a specific initiative between countries, out of strategic considerations for national security, economic exchanges, and international influence [16], a political relationship with other countries. Although bilateral political relations are relatively stable, they will change with changes in government power, political instability or some extreme events.

In international investment, the host government will provide a certain degree of preferential policies and diplomatic assistance for investment from countries with good relations. On the one hand, the longer the bilateral diplomatic relations are established, the more it helps the home country enterprises to understand the investment environment and policies of the host country, which is conducive to investors' foreign investment; on the other hand, through political exchanges and the construction of friendly cities [1], bilateral countries have established close and equal cooperative relations, increased the availability of information, reduced the political pressure of host governments on Chinese investors, and greatly improved the probability of successful investment by Chinese enterprises. From a network perspective of diplomatic relations, Jing $\mathrm{Li}$ proposed that for a close-knit national investor, the enterprise has considerable legitimacy or status, reducing the political concerns of the host country, while the host country's people friendly attitude [12]. Xiang Hongjin and others believe that due to the political conflict caused by the collision of interests between countries, the host government will transfer the cost of political conflict with the home country to the domestic home enterprises, using selective Laws, contracts and other means to obtain the rights of the home business, resulting in invalid or failure of foreign investment [26]. Therefore, changes in host country policies have a major impact on corporate foreign investment. When there is a political conflict between the two countries, it will worsen the investment environment of enterprises and increase the rate of investment failure. It can be seen that different bilateral political relations have different effects on the success or failure of Chinese enterprises' foreign investment. Based on the above analysis, we propose the following assumptions: 
Hypothesis 2: Bilateral political relations have a positive impact on the success rate of foreign investment, that is, the closer the bilateral political relations are, the higher the success rate of foreign investment.

\subsection{The Role of Bilateral Political Relations}

Bilateral political relations serve as an institutional link, and friendly bilateral relations can promote diplomatic and economic exchanges between the two countries. When the formal institutional distance between the two countries is small, that is, the laws and regulations are not much different, the success rate of foreign investment will increase. If the bilateral political relations between the two countries are friendly at this time, the host government will provide certain preferential policies and diplomatic assistance to the home country investment enterprises [27]. This helps investment companies overcome institutional differences in policy and legal system, and adapt to the investment environment as soon as possible, thereby enhancing investor confidence and increasing investment success rate [17]. When the formal systems of the two countries are far apart, there is a big gap between the legal norms between the two countries, and investment companies face more challenges and greater communication costs. If the bilateral political relations are alienated at this time, it will be difficult for investment enterprises to adapt to the investment environment of the host country and increase the complexity and uncertainty of investment. In addition, if bilateral political relations are not good, conflicts in the investment process are inevitable, and the success rate of investment will be greatly reduced. Political conflicts can also create tensions between the two sides [28], increasing the instability of investment on the basis of institutional mismatches and increasing the political pressure on home-based enterprises. Therefore, good bilateral political relations can weaken the negative relationship between institutional distance and the success rate of foreign direct investment, while alienated bilateral political relations will aggravate the negative impact of formal institutional distance and the success or failure of foreign investment. Based on the above analysis, we propose the following assumptions:

Hypothesis 3: Bilateral political relations have a negative adjustment effect on the influence of bilateral institutional distance and the success or failure of foreign investment. The closer the bilateral political relationship is, the more it can alleviate the negative impact of the bilateral system on the success rate of foreign investment.

\subsection{Re-Adjustment of Politically Sensitive Industries}

As China replaces the United States as the world's largest overseas asset purchaser, the European and American markets are increasingly cautious about the M\&A invitations of Chinese companies. National security and government interests have frequently become the reasons for the M\&A countries to strengthen their censorship and rejection. In 2016, Midea's acquisition of the German robot 
manufacturer KUKA caused more public attention and the vigilance of some German politicians. It tried to restrict the acquisition of Chinese enterprises in Germany, and even took action to lobby the EU to launch a merger review system to boycott Chinese companies. According to the Financial Times, 20 European transactions worth $\$ 16.3$ billion in 2016 were cancelled.

Globerman and others believe that when Chinese multinational corporations conduct overseas mergers and acquisitions [29], due to the host country's concerns about the corporate background and political goals of the home country, there is often opposition from political forces. The foreign-funded mergers and acquisitions security review system involving sensitive industries has become the main factor restricting the success of foreign investment. In recent years, while most countries have established sound trade protection measures, they have also revised the foreign M\&A laws of various countries, and foreign investment involving sensitive industries has been difficult. Therefore, if the investment involves sensitive industries, the host government will adopt a conservative or even defensive attitude to face foreign-invested enterprises, reduce the availability of information, and increase the risks and difficulties of foreign-invested enterprises. At this time, the closer bilateral political relations between the host country and the home country, the higher the purchase rate of foreign investment will be compared to the countries where bilateral political relations are generally unfriendly, and the negative adjustment effect of bilateral political relations will be strengthened. Based on the above analysis, we propose the following assumptions:

Hypothesis 4: The politically sensitive industry plays a regulatory role in the negative adjustment of bilateral institutional distance and the success or failure of foreign direct investment. If the foreign direct investment involves a politically sensitive industry, it will strengthen the negative adjustment of bilateral political relations.

\subsection{Re-Adjustment of the Nature of Property Rights}

Institutional economics refers to the nature of property rights as an important aspect of social economic systems. Therefore, the form of ownership is considered to be an important institutional feature based on the social system of the home country. Globerman et al. argue that because of host country concerns about the state-owned enterprise background and political goals of Chinese investment companies [29], Chinese companies face greater barriers to entry into host countries than other countries. Due to the special corporate governance structure of state-owned enterprises, the reasons for the failure of cross-border mergers and acquisitions of large state-owned enterprises in China are mainly concentrated on the characteristics of high political risk and resource-based industries. China's national conditions determine that most of the natural resources involved in oil, hydropower and other state-owned enterprises are characterized by this. Therefore, when Chinese enterprises invest abroad, they are 
often restricted by the host country. In addition, if a private company conducts an overseas merger, it is usually considered a commercial activity. When state-owned enterprises make commercial acquisitions or overseas investments, it is likely that the government will be resisted by the host country. Although the success or failure of foreign investment is affected by the economic strength of the home country's enterprises, the state-owned nature of the enterprise will bring invisible political and economic pressure to the host government. The Chinese government's support for state-owned enterprises' foreign investment will also cause the host country's approval department to refuse approval for reasons of national security or trade protection. As the object of foreign trade of the home country government, the state-owned nature of the investment enterprise will bring certain political pressure to the host government. Therefore, compared with non-state-owned enterprises, the adjustment role of bilateral political relations will be strengthened to some extent. Based on the above analysis, we propose the following assumptions:

Hypothesis 5: The nature of property rights plays a regulatory role in the negative adjustment of institutional distance and the success or failure of foreign direct investment in bilateral political relations. When investment enterprises are state-owned enterprises, they can strengthen the negative adjustment of bilateral political relations.

\section{Empirical Analysis}

\subsection{Data Sources}

This paper selects the US Heritage Foundation's 2005-2016 China Global Investment Tracker data on Chinese companies' external investment as an initial sample. As of 2016, Chinese companies have invested in 166 countries or regions around the world. After removing data-deficit countries and tax haven countries, as well as special political relations such as Hong Kong, Macao and Taiwan, they have received samples of 142 host countries.

\subsection{Variable Selection and Measurement}

The dependent variable of this paper is the success of the company's foreign investment (Completion), if the enterprise's foreign investment is successful, it is 1 , otherwise 0 . The explanatory variables in this paper include the following variables:

1) Institutional distance

According to the existing literature on institutional distance, this paper uses the World Bank's World Governance Indicators (WGI) to WGI Index: Freedom of Expression And government responsibility, political stability, government efficiency, regulatory quality, legal rules, control, and corruption. This paper obtains the quality of the host country system through six special indexes. Based on the WGI index, the absolute distance between the two countries is established, that is, the distance (id) of the host country system. 


\section{2) Bilateral political relations}

We use the results of the two countries' vote in the United Nations to measure. The voting data mainly comes from Strezhnev and Voeten (Bailey, Strezhnev, \& Voeten, 2017). The consistency formula for United Nations voting: diplomatic relations $\mathrm{P}=1-2 \times d / d_{\max }, d$ is the metric distance between the votes of the total binary members, $d_{\max }$ is the maximum possible distance of these votes in a given year, and the bilateral political relationship (pov) is calculated.

3) Politically sensitive industries

This article refers to Li Shi et al. on the definition of politically sensitive assets [21], and codes the politically sensitive industries of each country in turn: resource-based industries (oil, minerals, natural gas, etc.), transportation industry (aviation railway), defense security industry (military, nuclear, etc.), communication high-tech industry (microelectronics, cryptography, biotechnology, etc.). If an industry is involved, the industry's dummy variable (psi) takes a value of 1 , otherwise it is zero.

4) Nature of property rights (npr)

The state-owned nature is 1 , otherwise it is 0 . The data is mainly from CSMAR database.

5) Control variable selection

Geographical distance (gd), taking the logarithm of the actual distance between China and the host country's capital; the host country's gross national product (gdp) reflects the market size, and the growth rate of GDP reflects the growth of the local market. Potential (gdpg), the proportion of import and export trade to GDP reflects the degree of dependence of a country on the international market (open), and the proportion of high-tech exports to total exports reflects the host country's high-tech (hightec). The actual interest rate of the host country reflects the economic level of a country, and the control variables are processed by natural logarithm. The above data are derived from the World Development Indicators (WDI).

\subsection{Model and Empirical Results Analysis}

$$
\begin{aligned}
\text { Completion }_{i j}= & \sum \operatorname{control}_{i j-1}+i d_{i j-1}+\operatorname{pov}_{i j-1}+\varepsilon_{i j-1} \\
\text { Completion }_{i j}= & \sum \operatorname{control}_{i j-1}+i d_{i j-1}+\operatorname{pov}_{i j-1}+i d_{i j-1} * p o v_{i j-1}+\varepsilon_{i j-1} \\
\text { Completion }_{i j}= & \sum \operatorname{control}_{i j-1}+i d_{i j-1}+p o v_{i j-1}+p s i_{i j-1}+i d_{i j-1} * p o v_{i j-1} \\
& +i d_{i j-1} * p s i_{i j-1}+i d_{i j-1} * p o v_{i j-1} * p s i_{i j-1}+\varepsilon_{i j-1} \\
\text { Completion }_{i j}= & \sum \operatorname{control}_{i j-1}+i d_{i j-1}+p o v_{i j-1}+n p r_{i j-1}+i d_{i j-1} * p o v_{i j-1} \\
& +i d_{i j-1} * n p r_{i j-1}+i d_{i j-1} * p o v_{i j-1} * n p r_{i j-1}+\varepsilon_{i j-1}
\end{aligned}
$$

Among them, id and pov represent bilateral institutional distance and bilateral politics, respectively, psi and npr represent politically sensitive industries and property rights. Control represents control variables, and $i$ and $j$ represent host countries and years, respectively. Based on the construction of the econometric model in this paper, Table 1 lists the meanings of each variable and descriptive statistics. Table 2 is a correlation analysis between variables. 
Table 1. Descriptive statistics.

\begin{tabular}{cccccc}
\hline Variable & $\mathrm{N}$ & Mean & $\mathrm{SD}$ & Min & Max \\
\hline completion & 2002 & 0.9 & 0.3 & 0 & 1 \\
id & 1983 & 0.54 & 1.01 & -1.43 & 2.39 \\
pov & 1548 & 0.8 & 0.22 & 0 & 1 \\
psi & 1999 & 0.65 & 0.48 & 0 & 1 \\
npr & 1999 & 0.78 & 0.42 & 0 & 1 \\
gd & 1999 & 8.89 & 0.52 & 6.86 & 9.87 \\
gdp & 1993 & 26.25 & 2.18 & 19.35 & 30.53 \\
gdpg & 1816 & 1.36 & 0.79 & -4.26 & 3.54 \\
hightec & 1682 & 1.74 & 1.67 & -7.45 & 4.26 \\
open & 1955 & 4.12 & 0.67 & -1.78 & 6.09 \\
rate & 1245 & 1.54 & 0.99 & -1.75 & 6.23 \\
\hline
\end{tabular}

Table 2. Correlation analysis table.

\begin{tabular}{|c|c|c|c|c|c|c|c|c|c|c|c|}
\hline & c & id & pov & psi & npr & $\mathrm{gd}$ & gdp & gdpg & H-tec & open & rate \\
\hline c & 1 & & & & & & & & & & \\
\hline id & -0.09 & 1 & & & & & & & & & \\
\hline pov & 0.11 & -0.72 & 1 & & & & & & & & \\
\hline psi & -0.07 & -0.17 & 0.13 & 1 & & & & & & & \\
\hline npr & 0.09 & -0.36 & 0.33 & 0.18 & 1 & & & & & & \\
\hline gd & -0.03 & 0.18 & -0.28 & -0.08 & -0.09 & 1 & & & & & \\
\hline gdp & -0.08 & 0.61 & -0.65 & -0.17 & -0.34 & 0.16 & 1 & & & & \\
\hline gdpg & 0.006 & -0.39 & 0.397 & 0.125 & 0.23 & -0.21 & -0.39 & 1 & & & \\
\hline h-tec & -0.09 & 0.49 & -0.39 & -0.03 & -0.24 & 0.063 & 0.44 & -0.24 & 1 & & \\
\hline open & 0.05 & 0.048 & 0.28 & -0.03 & 0.085 & -0.24 & -0.37 & 0.07 & 0.06 & 1 & \\
\hline rate & 0.07 & -0.36 & 0.36 & 0.08 & 0.17 & 0.06 & -0.35 & 0.15 & -0.13 & 0.01 & 1 \\
\hline
\end{tabular}

Table 3 returns the explanatory variables through the logit model, where model 1 includes only control variables. We can see that the results of foreign investment are closely related to the degree of trade openness of the host country and the intensity of resource technology. The bilateral political relationship in Model 2 is significantly positive for the success or failure of foreign investment, so bilateral political relations have a significant positive impact on the success or failure of foreign investment. According to the results of Model 3, we can see that the coefficient of bilateral institutional distance is significant and the sign is negative for the coefficient of success or failure of enterprises' foreign investment, indicating that the bilateral institutional distance has a significant positive impact on the success or failure of foreign investment. Hypotheses 1 and 2 are verified. Model 4 tests the regulatory effect of bilateral political relations on 
Table 3. Investment success or failure.

\begin{tabular}{|c|c|c|c|c|c|c|}
\hline Variables & Model 1 & Model 2 & Model 3 & Model 4 & Model 5 & Model 6 \\
\hline id & & & $\begin{array}{c}-0.037^{* *} \\
(0.017)\end{array}$ & $\begin{array}{c}-0.089^{* * *} \\
(0.026)\end{array}$ & $\begin{array}{c}-0.0505 \\
(0.042)\end{array}$ & $\begin{array}{l}0.0407 \\
(0.052)\end{array}$ \\
\hline pov & & $\begin{array}{c}0.0106^{* * *} \\
(0.004)\end{array}$ & $\begin{array}{l}0.00494 \\
(0.004)\end{array}$ & $\begin{array}{c}-0.00580 \\
(0.006)\end{array}$ & $\begin{array}{l}-0.0001 \\
(0.0104)\end{array}$ & $\begin{array}{l}0.026^{*} \\
(0.015)\end{array}$ \\
\hline psi & & & & & $\begin{array}{l}-0.0138 \\
(0.0675)\end{array}$ & \\
\hline $\mathrm{id}^{*}$ pov & & & & $\begin{array}{l}0.014^{\star * *} \\
(0.005)\end{array}$ & $\begin{array}{l}0.0092 \\
(0.008)\end{array}$ & $\begin{array}{c}-0.004 \\
(0.01)\end{array}$ \\
\hline $\mathrm{id}^{*} \mathrm{psi}$ & & & & & $\begin{array}{c}-0.0448 \\
(0.042)\end{array}$ & \\
\hline $\mathrm{pov}^{\star} \mathrm{psi}$ & & & & & $\begin{array}{l}-0.004 \\
(0.011)\end{array}$ & \\
\hline $\mathrm{id}^{\star} \mathrm{pov}^{\star} \mathrm{psi}$ & & & & & $\begin{array}{l}0.0044 \\
(0.009)\end{array}$ & \\
\hline npr & & & & & & $\begin{array}{l}0.299^{* * *} \\
(0.096)\end{array}$ \\
\hline id ${ }^{\star}$ npr & & & & & & $\begin{array}{c}-0.15^{\star * *} \\
(0.054)\end{array}$ \\
\hline $\mathrm{pov}^{\star} \mathrm{npr}$ & & & & & & $\begin{array}{c}-0.037^{\star \star} \\
(0.015)\end{array}$ \\
\hline $\mathrm{id}^{\star} \mathrm{pov}^{\star}$ npr & & & & & & $\begin{array}{l}0.022^{\star *} \\
(0.011)\end{array}$ \\
\hline gd & $\begin{array}{l}0.0115 \\
(0.019)\end{array}$ & $\begin{array}{l}0.0416^{*} \\
(0.022)\end{array}$ & $\begin{array}{l}0.0423^{*} \\
(0.022)\end{array}$ & $\begin{array}{l}0.0254 \\
(0.023)\end{array}$ & $\begin{array}{l}0.0267 \\
(0.023)\end{array}$ & $\begin{array}{l}0.0219 \\
(0.023)\end{array}$ \\
\hline gdp & $\begin{array}{l}0.00038 \\
(0.007)\end{array}$ & $\begin{array}{l}-0.002 \\
(0.007)\end{array}$ & $\begin{array}{l}0.0083 \\
(0.008)\end{array}$ & $\begin{array}{l}0.0146 \\
(0.008)\end{array}$ & $\begin{array}{l}0.0087 \\
(0.009)\end{array}$ & $\begin{array}{c}0.0186^{* *} \\
(0.009)\end{array}$ \\
\hline gdpg & $\begin{array}{c}-0.0087 \\
(0.016)\end{array}$ & $\begin{array}{c}-0.0124 \\
(0.016)\end{array}$ & $\begin{array}{c}-0.0141 \\
(0.016)\end{array}$ & $\begin{array}{c}-0.0158 \\
(0.016)\end{array}$ & $\begin{array}{c}-0.0139 \\
(0.016)\end{array}$ & $\begin{array}{c}-0.0166 \\
(0.016)\end{array}$ \\
\hline open & $\begin{array}{c}0.057^{* * *} \\
(0.02)\end{array}$ & $\begin{array}{c}0.055^{* * *} \\
(0.02)\end{array}$ & $\begin{array}{c}0.075^{\star * *} \\
(0.022)\end{array}$ & $\begin{array}{l}0.059^{* *} \\
(0.023)\end{array}$ & $\begin{array}{l}0.052^{\star *} \\
(0.023)\end{array}$ & $\begin{array}{l}0.058^{* *} \\
(0.023)\end{array}$ \\
\hline hightec & $\begin{array}{c}-0.02^{\star * *} \\
(0.007)\end{array}$ & $\begin{array}{l}-0.02^{\star * *} \\
(0.0073)\end{array}$ & $\begin{array}{c}-0.017^{\star *} \\
(0.007)\end{array}$ & $\begin{array}{c}-0.02^{\star * *} \\
(0.007)\end{array}$ & $\begin{array}{l}-0.01^{* *} \\
(0.007)\end{array}$ & $\begin{array}{c}-0.019^{* *} \\
(0.007)\end{array}$ \\
\hline rate & $\begin{array}{c}0.009 \\
(0.012)\end{array}$ & $\begin{array}{c}0.004 \\
(0.0117)\end{array}$ & $\begin{array}{c}0.004 \\
(0.0117)\end{array}$ & $\begin{array}{c}0.0035 \\
(0.0116)\end{array}$ & $\begin{array}{c}0.0034 \\
(0.0116)\end{array}$ & $\begin{array}{c}0.0037 \\
(0.0116)\end{array}$ \\
\hline Constant & $\begin{array}{l}0.587^{\star} \\
(0.326)\end{array}$ & $\begin{array}{c}0.357 \\
(0.337)\end{array}$ & $\begin{array}{l}0.0430 \\
(0.370)\end{array}$ & $\begin{array}{c}0.158 \\
(0.371)\end{array}$ & $\begin{array}{c}0.316 \\
(0.384)\end{array}$ & $\begin{array}{l}-0.169 \\
(0.387)\end{array}$ \\
\hline Observations & 964 & 964 & 962 & 962 & 962 & 962 \\
\hline
\end{tabular}


institutional distance and the success or failure of foreign investment. In the following table, we conclude that the negative regulation of bilateral political relations is significant. Explain that effectively improving bilateral political relations is good for corporate foreign investment. The model 5 coefficient is not significant, indicating that there is no secondary regulation of bilateral political relations in the politically sensitive industry. The coefficient of Model 6 is significantly negative, indicating that the nature of the property rights of enterprises has a secondary adjustment relationship to the negative adjustment of bilateral political relations. That is, compared with non-state-owned, when state-owned enterprises invest abroad, the main effect of bilateral political relations The negative regulation effect is greater.

First, we choose diplomatic relations as a substitute for bilateral political relations. This article refers to the classification of Li Shi [30], and assigns bilateral relations to 0 - 10 according to their affinity. Secondly, because of the use of UN voting data as an explanatory variable, according to the study of Jing Li [12], we choose the establishment time as the instrumental variable (IV), and the two-stage least squares method to solve the potential endogeneity problem (see Table 4). From the website of the Ministry of Foreign Affairs of the People in the first phase, the ordinary least squares are used, the dependent variable is the consistency of the UN vote, and the explanatory variables include the number of years of diplomatic relations and other bilateral variables. In the second stage, the relevant fitting values of the United Nations vote and other relevant variables were brought into the model for analysis, and the results obtained were highly consistent with Table 3. Model 1 indicates that the institutional distance is significantly negatively correlated with the success or failure of foreign investment. Model 2 indicates that bilateral political relations have a significant negative adjustment effect on the main effect, while Model 3 can also see that the nature of property rights exists in the negative adjustment effect of bilateral political relations. The relationship of secondary regulation is shown in Table 5.

\section{Conclusions}

This paper combines institutional theory and political economy, and uses the empirical analysis of Chinese enterprises' foreign investment data from 2005 to 2016 to obtain the following conclusions. 1) The distance between bilateral systems has a significant negative impact on the success or failure of foreign investment, and bilateral political relations have a significant positive impact on the success or failure of foreign investment. 2) Bilateral political relations can regulate the relationship between the distance between the bilateral system and the success or failure of foreign investment. The close bilateral relationship between China and the host country can alleviate the adverse effects brought about by the institutional distance; and the alienated bilateral political relations will aggravate the negative effects of institutional distance and increase the failure rate of foreign investment. 3) Politically sensitive industries have no secondary adjustment effect on bilateral political relations, while the nature of property 
Table 4. Tool variable two-stage least squares.

\begin{tabular}{cc}
\hline Variables & Pov \\
\hline time & $0.000154^{* * *}$ \\
visits & $-0.0593^{* * *}$ \\
diplomacy & $0.0248^{* * *}$ \\
constant & $0.736^{* * *}$ \\
observations & 1547 \\
R-squared & 0.177 \\
\hline
\end{tabular}

${ }^{* *} p<0.01,{ }^{* *} p<0.05,{ }^{*} p<0.1$

Table 5. Endogenous test.

\begin{tabular}{|c|c|c|c|}
\hline Variables & Model 1 & Model 2 & Model 3 \\
\hline \multirow{2}{*}{ id } & $-0.190^{* * *}$ & $-0.249^{* * *}$ & 0.0275 \\
\hline & $(0.0702)$ & $(0.0752)$ & $(0.145)$ \\
\hline \multirow[b]{2}{*}{$p$} & -0.0512 & $-1.377^{\star}$ & 2.427 \\
\hline & $(0.446)$ & $(0.714)$ & $(2.067)$ \\
\hline \multirow[b]{2}{*}{ npr } & & & $0.782^{* * *}$ \\
\hline & & & $(0.263)$ \\
\hline \multirow{2}{*}{$\mathrm{id}^{*} \mathrm{p}$} & & $1.229^{\star *}$ & -1.403 \\
\hline & & $(0.505)$ & $(1.252)$ \\
\hline \multirow{2}{*}{$\mathrm{id}^{\star} \mathrm{npr}$} & & & $-0.318^{\star *}$ \\
\hline & & & $(0.154)$ \\
\hline \multirow{2}{*}{$p^{*} n p r$} & & & $-4.411^{* *}$ \\
\hline & & & $(2.215)$ \\
\hline \multirow{2}{*}{$\mathrm{id}^{*} \mathrm{p}^{\star} \mathrm{npr}$} & & & $3.434^{\star *}$ \\
\hline & & & (1.379) \\
\hline \multirow{2}{*}{ gd } & 0.154 & 0.130 & 0.134 \\
\hline & $(0.0944)$ & $(0.0953)$ & $(0.0977)$ \\
\hline \multirow{2}{*}{ gdp } & 0.0574 & $0.0737^{\star *}$ & $0.0866^{* *}$ \\
\hline & $(0.0360)$ & $(0.0366)$ & $(0.0387)$ \\
\hline \multirow{2}{*}{ gdpg } & -0.0924 & -0.0910 & -0.123 \\
\hline & $(0.0851)$ & $(0.0858)$ & $(0.0911)$ \\
\hline \multirow{2}{*}{ open } & $0.370^{* * *}$ & $0.334^{* * *}$ & $0.367^{* * *}$ \\
\hline & $(0.105)$ & $(0.106)$ & $(0.112)$ \\
\hline \multirow{2}{*}{ hightec } & $-0.111^{\star * \star}$ & $-0.107^{* *}$ & $-0.109^{* *}$ \\
\hline & $(0.0431)$ & $(0.0430)$ & $(0.0445)$ \\
\hline \multirow{2}{*}{ rate } & 0.0279 & 0.0234 & 0.0397 \\
\hline & $(0.0524)$ & $(0.0524)$ & $(0.0538)$ \\
\hline \multirow{2}{*}{ constant } & $-3.117^{\star}$ & $-3.063^{*}$ & $-4.200^{* *}$ \\
\hline & $(1.685)$ & (1.688) & $(1.815)$ \\
\hline observations & 961 & 961 & 961 \\
\hline
\end{tabular}

${ }^{* *} p<0.01,{ }^{* *} p<0.05,{ }^{*} p<0.1$. 
rights of enterprises can regulate bilateral political relations twice. The main performance is: when state-owned enterprises make foreign investment, the host government will reject Chinese enterprises because of factors such as national security or political pressure. Therefore, compared with non-state-owned enterprises, the adjustment role of bilateral political relations during the investment of state-owned enterprises will be more significant.

This paper explores whether there is a re-adjustment of the regulation of bilateral political relations from the perspectives of politically sensitive industries and the nature of corporate property rights. This is the innovation of this paper. The empirical results not only illustrate the necessity of the implementation of the current "One Belt, One Road" policy, but also have a far-reaching significance for developing China's foreign investment. The re-regulation of the nature of property rights also proves the importance of the nature of the enterprise in the process of foreign investment. The state-owned nature of the enterprise may cause the host country to refuse to accept investment due to political pressure and national security.

However, this article also has certain limitations. On the one hand, whether there are other relations in the politically sensitive industry needs more scholars to further explore and distinguish different industries to study the specific impact of political relations on the success or failure of investment. On the other hand, future scholars can also conduct research from the perspective of industry and property rights, and explore the sensitivity of bilateral political relations to the relationship between institutional distance and business operation costs. Based on the above analysis, how to improve the investment success rate of Chinese enterprises when investing abroad, the practical guidance of this paper lies in the following aspects:

On the one hand, correctly grasp the negative impact of institutional distance on the success or failure of investment. In the process of conducting foreign investment, enterprises should fully consider the differences between the host country and China in the legal system and cognition, conduct targeted regional investment, effectively avoid investment risks, and strive to reduce the investment cost of investment as much as possible, thereby increasing the success rate of investment. For areas that differ greatly from our system, we must prepare before investing, understand the local market and industry conditions, and ensure that we can respond to investment uncertainty in a variety of ways, thereby reducing investment risks.

In addition, make full use of and play an active role in bilateral political relations. According to the dynamic changes in bilateral political relations, timely and effective adjustment of investment plans, for countries with good diplomatic relations with China to make full use of effective resources for regional investment. With China's current "One Belt, One Road" policy, enterprises should actively develop economic partnerships with countries along the line, and integrate the maximum resources of the country's political mutual trust, economic integration, and culturally inclusive interests to conduct effective investment. As 
China's economic influence in the world is increasingly prominent, enterprises need to actively improve multilateral cooperation, pay more attention to the role of property rights in the process of foreign investment, and of course, be good at using bilateral political relations to increase the success rate of foreign investment.

\section{Conflicts of Interest}

The author declares no conflicts of interest regarding the publication of this paper.

\section{References}

[1] Yang, L.X., Liu, X.G. and Zhang, J. (2016) How Bilateral Political Relations Affect Foreign Direct Investment-Based on Binary Margin and Investment, The Perspective of Success and Failure. China Industrial Economy, No. 11, 56-65.

[2] Dunning, J.H. (1998) Location and the Multinational Enterprise: A Neglected Factor? Journal of International Business Studies, 29, 45-66. https://doi.org/10.1057/palgrave.jibs.8490024

[3] Buckley, P.J., Clegg, L.J., Cross, A.R., Liu, X., Voss, H. and Zheng, P. (2007) The Determinants of Chinese outward Foreign Direct Investment. Journal of International Business Studies, 38, 499-518. https://doi.org/10.1057/palgrave.jibs.8400277

[4] Alston, L.J. (1990) Institutions, Institutional Change, and Economic Performance. Journal of Economic Behavior \& Organization, 18, 142-144. https://doi.org/10.1016/0167-2681(92)90062-G

[5] Rui, H. and Yip, G.S. (2008) Foreign Acquisitions by Chinese Firms: A Strategic Intent Perspective. Journal of World Business, 43, 213-226. https://doi.org/10.1016/j.jwb.2007.11.006

[6] Kolstad, I. and Wiig, A. (2012) What Determines Chinese outward FDI? Journal of World Business, 47, 26-34. https://doi.org/10.1016/j.jwb.2010.10.017

[7] Habib, M. and Zurawicki, L. (2002) Corruption and Foreign Direct Investment. Journal of International Business Studies, 33, 291-307. https://doi.org/10.1057/palgrave.jibs.8491017

[8] Qi, C.L. and Zou, C. (2016) Quality of Institutional System, Institutional Distance and China's Foreign Direct Investment Location. Contemporary Finance and Economics, No. 7, 100-109.

[9] Kostova, T. and Zaheer, S. (1999) Organizational Legitimacy under Conditions of Complexity: The Case of the Multinational Enterprise. Academy of Management Review, 24, 64-81. https://doi.org/10.5465/amr.1999.1580441

[10] Zhang, J.H. and Zhou, C.H. (2010) Institutional Barriers to Chinese Enterprises Going Global-Taking Overseas Acquisitions as an Example. Economic Research, No. 6, 80-89.

[11] Morosini, P., Shane, S. and Singh, H. (1998) National Cultural Distance and Cross-Border Acquisition Performance. Journal of International Business Studies, 29, 137-158. https://doi.org/10.1057/palgrave.jibs.8490029

[12] Li, J., Meyer, K.E., Zhang, H. and Ding, Y. (2018) Diplomatic and Corporate Networks: Bridges to Foreign Locations. Journal of International Business Studies, 49, 659-683.

[13] Gupta, N. and Yu, X. (2009) Does Money Follow the Flag? Social Science Electronic 
Publishing, New York.

[14] Zhang, J.H., Wei, X.J. and Hai, K.E. (2010) Analysis of the Factors Affecting the Success or Failure of Chinese Enterprises' Overseas Acquisitions. Journal of Management World, No. 3.

[15] Jiang, G.H. (2015) Institutional Differences, Cultural Distance and Risks of Chinese Enterprises' Foreign Direct Investment. World Economic Research, No. 8, 37-47.

[16] Pan, Z. and Jin, Z.K. (2015) Bilateral Political Relations, Host Country Institutional Risks and China's Foreign Direct Investment. Finance and Trade Economy, No. 6, 85-94.

[17] Liu, X.G. and Yang, L.X. (2016) Bilateral Political Relations, Host Country System Environment and Foreign Direct Investment. Financial Research, No. 12, 17-26.

[18] Zhang, J.H. and Jiang, J.G. (2012) A Study of the Impact of Bilateral Political Relations on China's Foreign Direct Investment. World Economics and Politics, No. 12, 133-142.

[19] Yai, D.Y. (2011) Institutional Distance, International Experience and Research on the Success or Failure of Chinese Enterprises' Overseas M \& A. Nankai Economic Research, No. 5, 75-84.

[20] Jia, J.Y. and Li, W. (2016) Distance, Strategic Motivation and Success or Failure of Chinese Enterprises in Transnational M \& A-Based on Institutions and Springboard Theory. Nankai Management Review, 19, 122-132.

[21] Li, S. and Wu, C.P. (2016) An Empirical Study of the Factors Affecting the Success or Failure of Chinese Enterprises' Transnational M \& A-Based on Political and Cultural Perspectives. Nankai Management Review, 19, 18-30.

[22] Chen, Y. and Guo, W.B. (2018) Institutional Risks and Success or Failure of Transnational Mergers and Acquisitions: The Adjustment of "Soft Power" in Diplomatic and Economic Powers of Great Powers. World Economic Research, No. 5, 51-60.

[23] Feng, H. (2016) Institutional Factors and Foreign Direct Investment Research of Chinese Enterprises. Shandong University, Jinan.

[24] Li, Y. (2009) Study on the Effectiveness of Chinese Enterprises' Foreign Direct Investment. Management World, No. 9, 34-43.

[25] Peng, M.W., Wang, D.Y.L. and Jiang, Y. (2008) An Institution-Based View of International Business Strategy: A Focus on Emerging Economies. Journal of International Business Studies, 39, 920-936. https://doi.org/10.1057/palgrave.jibs.8400377

[26] Xiang, H.J., Ke, K.L. and Feng, Z.X. (2009) Theoretical and Empirical Study on the Determination of Anti-dumping Industry Damage-Based on COMPAS Model Type Analysis. China Industrial Economy, No. 1, 42-51.

[27] Dikova, D., Sahib, P.R. and Witteloostuijn, A.V. (2010) Cross-Border Acquisition Abandonment and Completion: The Effect of Institutional Differences and Organizational Learning in the International Business Service Industry, 1981-2001. Journal of International Business Studies, 41, 223-245. https://doi.org/10.1057/jibs.2009.10

[28] Li, Q. and Vashchilko, T. (2010) Dyadic Military Conflict, Security Alliances, and Bilateral FDI Flows. Journal of International Business Studies, 41, 765-782. https://doi.org/10.1057/jibs.2009.91

[29] Globerman, S. and Shapiro, D. (2009) Economic and Strategic Considerations Surrounding Chinese FDI in the United States. Asia Pacific Journal of Management, 26, 163-183. https://doi.org/10.1007/s10490-008-9112-5

[30] Li, S., Huang, S.Z. and Wu, C.P. (2017) Experience Research on Chinese Enterprises' Mergers and Acquisitions of Sensitive Overseas Assets. World Economics, No. 3, 99-108. 